\title{
PERSPECTIVES OF PARENTS ON THE IMPLEMENTATION OF THE NATIONAL LIFE-SKILLS AND HIV/AIDS EDUCATION PROGRAMME IN SECONDARY SCHOOLS IN ETHEKWINI, KWAZULU-NATAL
}

\section{Tanusha Raniga}

\section{INTRODUCTION}

Around the world an estimated 2.5 million children younger than 15 are living with HIV/AIDS (UNAIDS, 2007). Sub-Saharan Africa bears the brunt of the epidemic and its effect on young people. It is home to over $70 \%$ of young people living with the virus and up to $90 \%$ of children orphaned as a result of AIDS in the world (UNAIDS, 2007). If current infections continue and there is no large-scale treatment, care and support provided to young people infected, then up to $60 \%$ of 15-year-olds will not reach the age of 60 (UNAIDS, 2004). In countries such as South Africa and Zimbabwe, where a fifth of the adult population is infected, AIDS is set to claim the lives of around half of all 15-year-olds. In Botswana, where about one in three adults are infected, no fewer than two thirds of 15 -year-old boys will die prematurely of AIDS. These findings are contained in a United Nations Report (2004) that shows that current trends of infection will increasingly have an impact on demographics such as rates of infant, youth and adult mortality, life expectancy and economic growth in many developing countries.

Although prevention is the foundational response to AIDS, ignorance about the epidemic remains pervasive among young people, many of whom do not know how to protect themselves from HIV. In Sub-Saharan Africa only $8 \%$ of young people have access to education on prevention (UNAIDS, 2004). Additionally, many young people have an attitude of invincibility and do not believe that HIV is a threat to them. More than two thirds of sexually active girls aged 15-19 in Haiti and more than half of girls in the same age group in Zimbabwe do not believe that they run the risk of HIV infection (UNAIDS, 2007). Young people exposed to sexual abuse and exploitation are especially vulnerable to infection. In Cambodia $30 \%$ of sex workers aged 13-19 are infected with the virus. Of the estimated 2 million sex workers in India, $20 \%$ are under the age of 15 and nearly $50 \%$ under age 18. In South Africa young people under the age of 20 constitute $44 \%$ of the national population and socio-structural factors such as high unemployment rates, poverty and violence have increased their vulnerability to HIV. Over 20\% in the age group 15-19 are infected (Van Rensburg, Friedman, Ngwena, Pelser, Steyn, Booysen \& Adendorff, 2002). There is also evidence that a prevalence of infections among young girls is linked to gender-based violence in homes, schools, the work place and other social spheres (Sathiparsad \& Taylor, 2006).

As an acknowledgement of the serious psycho-social and economic implications of HIV/AIDS on young people, in August 1999 the South African Ministry of Education released the National Policy on HIV/AIDS for learners and educators in public schools, and students and educators in further education and training institutions (Department of Education, 1999). One key component included in the Policy is that of "Education on HIV/AIDS", which stipulates that "a continuing life-skills and HIV/AIDS education programme must be implemented at all schools for all learners, students, educators and other staff members" (Department of Education, 1999:2). Additionally, the Department of Education obtained a directive through the National Integrated Plan for children affected and infected with HIV/AIDS (Departments of Education, Health and Social Development, 2000) to implement the life-skills, sexuality and HIV/AIDS education programmes at schools in order to prevent new infections among the 
youth. Hence, the implementation of life skills, sexuality and HIV/AIDS education programmes in schools is a tangible outcome of both the Policy and the National Integrated Plan.

This paper presents the empirical findings of a larger study which investigated how secondary schools have responded to the problem of HIV/AIDS, the challenges faced by educators in the implementation of the National HIV/AIDS School Policy and the Life-Skills programme, and evaluated the Life-Skills, HIV/AIDS education programme implemented in schools. Using qualitative methodology, which comprised interactive workshops with a total of 14 parents of Grade 9 learners from an urban formal school, an urban informal school and a rural school from the eThekwini region, KwaZulu-Natal, this paper highlights a unique attempt to understand the extent to which parents were involved in HIV/AIDS intervention programmes at the three selected schools. The findings reveal three key themes which form the central premise of this paper: "sex is something that we are not comfortable talking to our children about"; the integration of sexuality programmes in schools; and "HIV/AIDS is killing our people and as community members we don't know what to do". Recommendations are made for schools to be established as "one-stop care centres" and the inclusion of social workers in schools.

\section{THE NATIONAL LIFE-SKILLS AND HIV/AIDS EDUCATION PROGRAMME}

After 1994 the South African government placed great emphasis on prevention strategies with little focus on treatment, care and support for those individuals infected with, and or affected by, HIV/AIDS (Van Rensburg et al., 2002). Magnani, MacIntyre, Karim, Brown and Hutchinson (2005) reveal that even though the South African government's response to the epidemic has been inconsistent, one positive outcome has been the mandatory integration of the Life-Skills, HIV/AIDS education programme in secondary schools. The National HIV/AIDS School Policy and the National Integrated Plan for children infected and affected by HIV/AIDS are two foundational policies that provide the directive for the integration of the Life-Skills, HIV/AIDS education programme in schools. There is also agreement expressed by Van Dyk $(2001,2005)$, Strydom (2003), and Sewpaul and Raniga (2005) that for life-skills, sexuality and HIV/AIDS education programmes to be successful, there is a need to include parents as key stakeholders in the community. It is positive to note that the National Integrated Plan (Departments of Education, Health and Social Development, 2000), the HIV/AIDS: care and support of affected and infected learners training guide for educators (Department of Health, 2001) and the National HIV/AIDS School Policy (Department of Education, 1999) acknowledge the importance of parents as key stakeholders in the implementation of the Life-Skills and HIV/AIDS education programme.

One of the key points made in the National HIV/AIDS School Policy that has implications for the implementation of the Life-Skills, HIV/AIDS education programme within schools is that "it is imperative that each school must have a planned strategy to cope with the epidemic" (Department of Education, 1999:4). Following from this, it is envisaged that the primary responsibility for the implementation of the Policy lies with the school governing bodies, on which parents are represented. However, this is based on the assumption that governing bodies already have the skills and expertise to develop such an implementation plan. In a preliminary study conducted by Sewpaul and Raniga (2005), educators were of the opinion that this is an unrealistic responsibility for parents and school governing bodies as parents are rarely involved in developing HIV/AIDS implementation plans at schools. This study was a unique attempt to investigate the level of involvement of parents in HIV/AIDS intervention programmes in secondary schools in the eThekwini region, KwaZulu-Natal. 


\section{RESEARCH METHODOLOGY}

\section{Research design}

The study was approved by the Research Ethics Committee of the University of KwaZuluNatal. Using qualitative methodology of formative programme evaluation, interactive workshops were held with 14 parents of Grade 9 learners from an urban formal school, an urban informal school and a rural school in the eThekwini region of KwaZulu-Natal in South Africa. Smith (1990:5) contends that programme evaluation is the application of a research methodology that will help the researcher answer questions about the operations and impact of social programmes. The emphasis of this study was on gaining insight through documenting and describing the operations of the National Life-Skills, HIV/AIDS education programme rather than on whether programme goals were achieved. In so doing, the Department of Education's life-skills training manuals, the National Integrated Plan for children infected and affected by HIV/AIDS (Departments of Education, Health and Social Development, 2000) and the National HIV/AIDS School Policy (Department of Education, 1999) were reviewed in order to obtain a comprehensive understanding of the Life-Skills programme. This study utilised what Dimock (1997) categorises as self reports by learners and parents, direct observation and review of the relevant policy documents. This paper provides insights into the perspectives of parents on the implementation of the National Life-skills and HIV/AIDS education programme in three targeted schools.

\section{Selection of the schools}

The workshops with the parents were preceded by several telephonic contacts and meetings at the schools with principals and the Life Orientation educators. The purpose of these visits was to obtain consent and commitment from the school personnel in respect of organising and facilitating the workshops with parents. The workshops were conducted in a secondary school from a rural area of Ndwedwe East, an urban formal area of Amanzimtoti and an urban informal area of Inanda respectively. The selection of the targeted schools was made from a broader sample of 74 secondary schools which comprised a quantitative audit of the National Life-skills and HIV/AIDS school Policy in the eThekwini region (Raniga, 2007). Using the criterion sampling method, the following criteria were used to select the schools:

- The school must be implementing the Life-Skills, HIV/AIDS education programme with learners in Grades 8 and 9 as this is stipulated in the Department of Education's National Integrated Plan (2000);

- Educators must have received training on the implementation of the Life-Skills programme from the KwaZulu-Natal Department of Education;

- Location of the school: one urban formal school, one urban informal school and one rural school were chosen;

- Willingness on the part of principals to allow learners, parents and educators to participate in the study.

The researcher felt it imperative to select one urban formal school, one urban informal school and one rural school in order to gain insight into the varied experiences of the parents of learners regarding the Life-Skills education programme. This was fundamental as fourteen years into the new democracy in South Africa not all schools have racially mixed learner populations. Additionally, the disparity in access to basic services and resources at the various schools impacts on the institutional capacity to implement the programme (Raniga, 2007). It 
was not the intention of this study to make any claim that the Life-Skills programme resulted in specific outcomes. Instead the focus of the study was on an in-depth description and analysis of the Life-Skills, HIV/AIDS education programme from the perspectives of parents, learners and educators with the aim of improving and strengthening the implementation of the programme. This paper documents the perspectives of parents on the implementation of the Life-Skills, HIV/AIDS education programme in three selected schools, the level of involvement in the programme and their roles as sexuality educators.

\section{Selection of participants}

Non-probability, purposive sampling was used to select the Grade 9 learners and their parents at the three selected schools. Marlow (1998:22) says that "purposive sampling allows the researcher to intentionally select those elements that are information rich which is relevant for qualitative research". The workshop with the parents followed from workshops implemented with the 114 Grade 9 learners from the three selected schools. A total of 114 invitations were given out to parents of the Grade 9 learners from the three selected schools. However, a total of 14 parents attended the sessions. This small number is acknowledged as a limitation that was beyond the control of the researcher during the study. It was possible that because of the sensitive nature of the topics for discussion (sexuality education and HIV/AIDS programmes taught at schools), some of the learners did not pass on the invitations to their parents or caregivers. The Life Orientation educators and principals at the three selected schools also indicated that this was a pattern experienced for all parent meetings organised by the schools. Despite this limitation, the quality of information shared by those parents that did attend and actively contributed to discussions on sexuality and HIV/AIDS programmes taught at schools was immensely valuable. More importantly, it reflected the concern that these parents had a dire need for information about dealing with the effects of HIV/AIDS in the wider community.

On a positive note, it was evident that as a consequence of the workshop held at the urban formal school, worthwhile networking did take place between the Life Orientation educator and the parents, as the need for increased communication and collaboration was identified during the workshop session. The Life Orientation educators from the three selected schools were present at the parent workshops to share their views about teaching on the Life-Skills, HIV/AIDS programme and discuss the content of the training material used with the learners in the classroom.

\section{Data-collection instrument}

At the rural school a total of six parents attended, while at the urban formal and urban informal schools, a total of four parents attended respectively. Each group of parents was given a series of questions, which guided their discussion during the session. The questions were based on the goals of the National HIV/AIDS School Policy (Department of Education, 1999) and the National Integrated Plan for children infected and affected by HIV/AIDS (Departments of Education, Health and Social Development, 2000) and the key objectives of the study. The questions were divided into two main streams: for those parents that answered positively in respect of their awareness of the Life-Skills, HIV/AIDS education programme and those that were unaware of it. There was a section on their general perceptions. The questions were framed as follows:

1. Are you aware of the Life-Skills, HIV/AIDS education programme taught to learners at school? If they answered yes, then the questions that followed were: 
1.1 What do you think about the content of the Life-Skills and HIV/AIDS programme taught to your children in the classroom?

1.2 How did you get to know about the programme?

1.3 Do you think that this was an appropriate way to get to know about the Life-Skills, HIV/AIDS education programme? Please give details.

1.4 Would you find it helpful to have more information about youth behaviour, health and development in your community?

2. If the parents answered no, then the questions asked were as follows:

2.1 What do you think about the Life-Skills, HIV/AIDS education programme being taught at schools?

2.2 What role should parents play in the planning and implementation of these programmes at schools?

2.3 Would you find it helpful to have more information about youth behaviour, health and development in your community?

3. The section on general perceptions had the following questions:

3.1 What role would you like to play as parents in helping the youth to make more informed sexual choices?

3.2 What else should be done to help us as parents to deal with the problem of HIV/AIDS in society?

3.3 How and from whom would like to receive this kind of help?

The workshops were facilitated by the researcher and a Zulu-speaking research assistant. Each group of parents in the respective school contexts was given 15 minutes to reflect on the questions individually and document their responses on flip-chart paper. Subsequently a plenary discussion was held with the researcher and Life Orientation educator, who was present at the session to discuss the responses. The duration of the workshops at each of the selected schools was one and a half hours. The workshops in the rural and urban informal schools were conducted in Zulu by the research assistant. It is possible that in translating field notes from these sessions from one language to another, some meaning may have been lost, although weekly feedback sessions were held with the research assistant to clarify the expressions and meanings captured during the session. The researcher found the process of identifying substantive points and categorising the data into major theme categories and theme clusters was useful to analyse the data (Gillham, 2000; Roberts \& Cairns, 1999).

\section{ANALYSIS AND DISCUSSION OF FINDINGS}

"Sex is something that we are not comfortable talking to our children about...."

A key theme that emerged from the data analysis of the parent workshops was parents' roles as sexuality educators. Parents from all three schools expressed that it is not always easy for them to talk about sexuality to their children. Some of the sentiments expressed by parents were:

We did not grow up in an environment in which sex was discussed, I do not know all the "right" answers. I feel confused about the proper amount of information to offer. As parents we need a lot of relevant information on sexuality and HIV/AIDS before we can inform our children. 
One parent from the rural community stated:

In our culture we just don't talk about sex to our children.

Another parent from the rural community stated that more information on youth behaviour would be helpful as "we as parents are concerned about the secretive behaviour of the youth that is when they do things and are not open about their behaviour".

It is clear from the comments made by parents that addressing a sensitive topic such as sexuality and HIV/AIDS with their children without adequate knowledge and skills in dealing with difficult questions was a challenge. Parents at the workshops expressed feelings of insecurity and unworthiness in their roles as sexuality educators and a lack of skills in dealing with the controversies and the sensitivity of sexuality and HIV/AIDS. Parents recommended that school personnel facilitate workshops on understanding the adolescent stage of life and parenting skills as well as communication skills, as this would equip them with the necessary knowledge and skills to deal with sexuality issues in the home environment. Van Dyk (2001, 2005) suggests that parents who are empowered become knowledgeable and comfortable discussing sex and topics such as understanding the body, adopting healthy behaviours, respecting others and dealing with feelings with their children as early in the life cycle as possible (before the pre-teen years).

\section{The integration of sexuality programmes in schools}

It was thus not surprising that there was a general optimism shared by parents about the inclusion of the programme in the school curriculum, as they were aware that it would benefit their children in terms of making appropriate sexual choices.

One parent from the rural area stated that:

The programme is an important one for our children in order to learn how to protect themselves and to avoid having more than one partner.

Another parent commented in the workshop session at the urban formal school that:

It is the job of the school to educate our children about sexuality and HIV/AIDS before they get misleading information from the wider society.

The comment made by the parent in the urban formal school (which was racially mixed) concurs with the previous theme that parents were generally not comfortable talking to their children about sexuality issues, even though HIV/AIDS has become a matter of life and death. Instead parents supported effective school-based sex education such as the implementation of the Life-Skills and HIV/AIDS programme. It is important, however, to take note of Van Dyk's (2001, 2005) argument that the most effective sexuality education for young people is when both parents and schools take equal responsibility and engage with young people on specific sexuality issues, questions or concerns in an open and transparent manner.

It was also interesting to note that the parents were of the view that the content of the LifeSkills, sexuality and HIV/AIDS education programmes needed to go beyond increasing knowledge and awareness of HIV/AIDS, and should include strategies to assist families of the learners who are either infected and/or affected by HIV/AIDS. This corroborates Strydom and Raath's (2005) study, which revealed that there is a need for a comprehensive programme on the social work treatment of the psychosocial needs of infected adolescents and their parents.

This leads to the discussion of another pertinent theme that emerged from the data analysis. 


\section{"HIV/AIDS is killing people everyday and as members of the community we don't know what to do..."}

In South Africa poverty and unemployment, compounded by HIV/AIDS, are major macro social problems that contribute to a sense of powerlessness of the family system. Gow and Desmond (2002), Barnett and Whiteside (2002), and Sekokotla and Mturi (2004) maintain that the declining productivity of breadwinners in families not only strains economic resources within families, but also the psycho-social and emotional roles between parent and children. Gow and Desmond (2002) state that this leads to roles between parent and child within families becoming blurred and adds to the powerlessness felt within the household system. Parents at the workshops confirmed this feeling of powerlessness when they asserted that HIV/AIDS is a profound reality in their own communities

One parent from the urban informal community commented:

It is not just persons living with the disease that are affected by the disease, but the entire family system is isolated from the community.

Another parent from the rural community added:

This is a reality in our communities as we observe the number of children orphaned as a result of HIV/AIDS is growing everyday.

It was clear from the views expressed by the parents that the communities in which they resided were experiencing social strain in coping with large numbers of people infected, and an everincreasing number of children orphaned as a result of HIV/AIDS. This also speaks to the maturation of the disease and current reality of HIV/AIDS across all communities. Furthermore, the sentiments expressed by the parents confirm the warning made by Gow and Desmond (2002), who poignantly stated that the numbers of persons infected and of children orphaned as a result of HIV/AIDS are increasing, while the community capacity to care for them without adequate support is shrinking. Sekokotla and Mturi (2004) add that the increased number of children orphaned means that formidable transformations have to occur at the individual, family and societal level to accommodate the heightened levels of mortality.

When asked about what could be done to address the situation, in the rural school parents spoke about the need to start support groups for families infected and/or affected by the epidemic. Others spoke about the need to resume the practice within the Zulu culture of having an elderly female guide teenage girls about their behaviour and values when the girl reaches puberty. This practice helps to uphold her respect and dignity and also ensures abstinence from sex until marriage. For the teenage boys, when they are in a relationship, they should have the advice of an elderly male from the same family who would guide and discuss safer sex practices such as ukusoma (thrusting of the penis between the thighs of a woman with no penetration) with them. Parents from the rural community stated that these practices are no longer maintained, because of the Western influences to the detriment of African cultural traditions, which are based on community values of "ubuntu".

All the parents at the workshops expressed that they needed more help and support from the school than is being provided to help the learners as well as families infected and/or affected with the virus. School personnel and the KwaZulu-Natal Department of Education need to make greater efforts to engage parents in the planning and implementation of HIV/AIDS intervention programmes at schools. Moreover, there was an urgent call by parents to establish institutionally based support systems at schools to holistically address the needs of parents and 
learners infected with and/or affected by HIV/AIDS. Following from this a key recommendation is for establishment of schools as "one-stop care centres".

\section{Schools as "one-stop care centres"}

It is evident that the school system serves as an important bridge between the learner, the family and the wider community context. The Australian context has gained international recognition for an innovative programme to deal with the complex interplay of the dynamics surrounding youth sexuality and HIV/AIDS, and bridging the gap between the school and home environment. The Australian National HIV/AIDS Strategy has similar positive intentions to the South African National HIV/AIDS School Policy (Department of Education, 1999) as the focus is on mitigating the infection rate among young people through HIV/AIDS education and prevention interventions within the school context. Corroborating the findings of this study, Mitchell, Ollis and Watson (2000) contends that HIV/AIDS prevention programmes in secondary schools in the Australian context have been somewhat ad hoc and uncoordinated despite a great deal of work being done in the area. She added that one key limitation of the school-based programmes was that the structure and content had narrowly focused on disease prevention rather than at more socially oriented health-promoting behaviours among the youth. Consequently in 1998 schools in Australia called for a national framework to provide a wholeschool approach to the teaching of HIV prevention. This approach is based on the premise that successful intervention programmes not only take into account the cognitive processes of the individual (responsible choices), but focuses on the social world in which the behaviours happen. The Australian whole-school approach formed the base for the introduction of the Health Promoting Schools (HPS) Model in South Africa (Department of Health, 2000a).

The Departments of Social Development, Health and Education acknowledge the HPS Model as an important strategy for addressing not just the HIV/AIDS crisis, but also other social problems such as poverty, violence, substance abuse and providing access to education to youths who have left the school system (Department of Health, 2000a). This commitment to promoting health and enhancing quality education for youth forms part of the objectives enshrined in the Tirisano Plan (Department of Education, 2000). Similar to the Australian context, a particular contribution of the HPS Model for the South African context is that it provides a framework for developing meaningful school-household-community relations in a coordinated and integrated manner. The National Guidelines for the development of Health Promoting Schools in South Africa maintains that Life-Skills education should be located within a comprehensive health-promoting school site (Department of Health, 2000a). The vision is the creation of a culture of effective teaching and learning through the holistic development of schools and other learning sites which will promote the optimal well-being of all members of the teaching and learning community ( Department of Health, 2000b:16).

Expanding on the principles enshrined in the HPS Model, a key recommendation of this study is for the establishment of schools as "one-stop care centres". Schools as "one-stop care centres" would be the ideal site to put in place comprehensive strategies which include prevention, treatment, care and supportive services to learners, their families as well as educators either infected and/or affected by the epidemic. This would include an integrated, coordinated and collaborative approach between both government and non-government sectors in providing a useful holistic, integrated strategy to helping learners, their parents and educators who are infected and/or affected by the epidemic at a "one-stop care centre". Furthermore, it would serve as an ideal site where social workers would work in collaboration with key stakeholders (parents, learners, educators, medical personnel, non-governmental organisations 
and government officials) within multidisciplinary teams, where different service providers cooperate and complement one another in the provision of services to learners, their families and educators who are either infected and/or affected by the epidemic.

\section{The inclusion of social workers at schools}

Parents were of the view that the inclusion of social workers in schools was imperative to educate and empower them with coping skills and also to provide the necessary counselling and support services for families and learners affected and/or infected by HIV/AIDS.

One parent from the urban formal school commented:

The Department of Education together with schools and the Department of Social

Development need to provide community-based support systems for families.

Research conducted by Sathiparsad and Taylor (2005), and Sewpaul and Raniga (2005) confirmed the need to integrate social work services into the school context. The action research in the preliminary study (Sewpaul \& Raniga, 2005) confirm that social workers are often in a position to facilitate collaboration and create a service network that deals with HIV/AIDS within the school in a holistic and integrated manner. In this study both parents and learners were of the view that the responsibility to include social workers in schools in order to establish care and support services to help communities manage and deal with the HIV/AIDS crisis lies with the Departments of Education, Health and Social Development (as indicated in the NIP document, 2000). In order to provide holistic and multiple intervention strategies to curb infection rates among the youth and to provide for appropriate care and support to learners infected and affected by the disease, all three departments need to work in partnership with each other.

Currently social workers in KwaZulu-Natal form part of the Psychological Guidance and Special Education Services (PGSES) of the Department of Education, with six social workers employed to service about 600 schools. The role of these social workers is mainly consultative to public schools and referrals are made both to community-based social workers employed in the NGO and the government welfare sector. This study reflects and confirms (Kasiram, 1994; Kemp, 2002; Livingstone, 1990; Sathiparsad \& Taylor, 2005; Sewpaul and Raniga, 2005) the dire need for the formalisation and extension of school social work services in the light of the maturation of the HIV/AIDS disease and the need to provide adequate treatment, care and support to learners, their families and educators either infected and/or affected by the epidemic.

\section{CONCLUSION}

When the devastating effects of HIV/AIDS on school-going youth are real, then parents and family relationships provide the most immediate form of support. The perspectives shared by 14 parents from a rural community, an urban formal community and an urban formal community on the integration of the Life-Skills programme into the school curriculum was positive. At the same time parents from mainly the rural and urban informal communities in this study claimed that communities were experiencing a social strain in coping with large numbers of people infected and affected by HIV/AIDS. Parents called for the inclusion of social workers in the school context and for the establishment of schools as "one-stop care centres" by the Provincial Departments of Education and Social Development as key support mechanisms to be put in place for learners, parents and educators who are either infected and/or affected by the epidemic. 


\section{REFERENCES}

BARNETT, T. \& WHITESIDE, A. 2002. AIDS in the Twenty-First Century: disease and globalisation. Wales: Palgrave Macmillan.

CAMPBELL, C. \& FOULIS, C.A. 2003. Youth sexuality and HIV/AIDS: a case study of a peri-urban community in KwaZulu-Natal. Unpublished paper presented at the Medical Research Council Forum, July 2003, Durban.

DEPARTMENT OF EDUCATION 1999. National Policy on HIV/AIDS, for learners and educators in Public Schools, and Students and Educators in Further Education and Training Institutions, Government Gazette Notice 1926 of 1999, Pretoria.

DEPARTMENT OF EDUCATION 2000. Implementation plan for Tirisano: January 2000December 2004. Pretoria: Department of Education.

DEPARTMENT OF HEALTH 1999. Life-skills and HIV/AIDS Education Programme. Pretoria.

DEPARTMENT OF HEALTH 2000a. HIV/AIDS \& STD Strategic Plan for South Africa 2000-2005. Pretoria: Department of Health.

DEPARTMENT OF HEALTH 2000b. National Guidelines for the Development of Health Promoting Schools/Sites in South Africa. Task Team Draft 4 October 2000. Pretoria.

DEPARTMENT OF HEALTH 2001. The HIV/AIDS: care and support of affected and infected learners: a guide for educators. The HIV/AIDS and STD Directorate, Department of Health, Pretoria.

DEPARTMENTS OF EDUCATION, HEALTH \& SOCIAL DEVELOPMENT. 2000. National Integrated Plan for children infected and affected by HIV/AIDS. Pretoria.

DIMCOCK, H.G. 1997. A simplified guide to programme evaluation. Ontario: Captus Press. GILLHAM, B. 2000. The research interview. London and New York: Continuum.

GOW, J. \& DESMOND, C. (eds), 2002. Impacts and interventions: the HIV/AIDS epidemic and the children of South Africa. Pietermaritzburg: University of Natal Press.

KASIRAM, M. 1994. School social work service delivery: models for future practice. Durban: University of Durban-Westville. (PhD Dissertation)

KEMP, M. 2002. Social work - an integral part of the Department of Education. Paper delivered at the $3^{\text {rd }}$ National Learner Support and development Conference. Durban 2-4 October.

LIVINGSTONE, B.J. 1990. South African school social work practice. In: McKENDRICK, B.W. (ed) Social work in action. Pretoria: Haum Tertiary: 235-245.

MAGNANI, R., MACINTYRE, K., KARIM, A.M., BROWN, L., HUTCHINSON, P. 2005. The impact of life skills education on adolescent sexual risk behaviors in KwaZulu-Natal, South Africa. Journal of Adolescent Health, 36:289-304.

MARLOW, C. 1998. Research methods for generalist social work ( $\left.{ }^{\text {nd }} \mathrm{ed}\right)$. Pacific Grove: Brookes/Cole Publishing Company. 
MITCHELL, A., OLLIS, D. \& WATSON, J. 2000. Talking sexual health: a national application of the health promoting school framework for HIV/AIDS education in secondary schools. The Journal of School Health, 70(6):262-265.

RANIGA, T. 2007. A critique of the South African national life-skills and HIV/AIDS school policy: lessons for policy adjustment. Social Work/Maatskaplike Werk, 43(1):66-76.

ROBERTS, J \& CAIRNS, K. 1999. School children with HIV/AIDS. Calgary, Alberta: Canada Detselig Enterprises Ltd.

SATHIPARSAD, R.. \& TAYLOR, M. 2005. Towards social work intervention in rural schools: perspectives of educators. Social Work/Maatskaplike Werk, 41(3):265-275.

SATHIPARSAD, R.. \& TAYLOR, M. 2006. Diseases come from girls: perspectives of male learners in rural KwaZulu-Natal on HIV infection and AIDS. Journal of Education HIV/AIDS Special Issue, (38):117-137.

SEKOKOTLA, D. \& MTURI, T. 2004. Effects of the HIV/AIDS Epidemic on the South African families. Loyola Journal of Social Sciences, (XVIII):189-211.

SEWPAUL, V. \& RANIGA, T. 2005. Producing results: researching social work interventions on HIV/AIDS in the context of the school. In: ADAMS, R., DOMINELLI, L. \& PAYNE, M. Social work futures: crossing boundaries, transforming practice. Wales: Palgrave MacMillan.

SMITH, J.M. 1990. Programme evaluation in the human services. New York: Springer Publishing Company.

STRYDOM, H. 2003. HIV/AIDS and South African adolescents: attitudes and information needs. Social Work/Maatskaplike Werk, 39(1):59-72.

STRYDOM, H. \& RAATH, H. 2005. The psychosocial needs of adolescents affected by HIV/AIDS: a South African study. International Social Work, 48(5):569-580.

UNAIDS 2004. Report on the Global AIDS Epidemic $-4^{\text {th }}$ global report (June). Geneva: UNAIDS.

UNAIDS 2007. Report on the Global AIDS Epidemic $-7^{\text {th }}$ global report. World Health Organisation UNAIDS. Geneva.

VAN DYK, A. 2001. HIV/AIDS care and counselling: a multidisciplinary approach $\left(2^{\text {nd }}\right.$ ed). Cape Town: Pearson Education.

VAN DYK, A. 2005. HIV/AIDS care and counselling: a multidisciplinary approach $\left(3^{\text {rd }}\right.$ ed). Cape Town: Pearson Education.

VAN RENSBURG, D., FRIEDMAN, I., NGWENA, C., PELSER, A., STEYN, F., BOOYSEN, F. \& ADENDORFF, E. 2002. Strengthening local government and civic responses to the HIV/AIDS epidemic in South Africa. Centre for Health Systems Research and Development. Bloemfontein.

Dr Tanusha Raniga, Lecturer, School of Social Work and Community Development, University of KwaZulu-Natal, Durban, South Africa. 